\title{
POSTMILENIALISME BERSYARAT: KRITIK TERHADAP ESKATOLOGI PREMILENIALISME DISPENSASIONAL DAN SEBUAH USULAN TERHADAP ESKATOLOGI PENTAKOSTA
}

\author{
Jessica Novia Layantara
}

\begin{abstract}
Abstraksi
Selama ini eskatologi Pentakosta selalu dihubungkan dengan pandangan premilenialisme dispensasional. Namun jika dianalisa, sebenarnya banyak hal di dalam premilenialisme dispensasional yang tidak sesuai dengan teologi Pentakosta. Artikel ini akan menjelaskan secara singkat sejarah bagaimana eskatologi Pentakosta dapat dipengaruhi oleh premilenialisme dispensasional, serta memberikan kritik-kritik yang membuktikan bahwa pandangan tersebut sebenarnya tidak bersesuaian secara esensial dengan pengajaran Pentakosta. Artikel ini juga akan mencoba mengusulkan sebuah model eskatologi postmilenialisme bersyarat (conditional postmillennialism), yang dipandang lebih sesuai untuk menjadi kerangka eskatologi Pentakosta.
\end{abstract}

Kata Kunci: Premilenialisme dispensasional, postmilenialisme, dispensasionalisme fundamental, eskatologi Pentakosta.

\section{Pendahuluan}

Gerakan Pentakosta seringkali dihubungkan dengan keunikan doktrin Roh Kudus (pneumatologi) yang berbeda dengan pandangan Kristen Protestan konservatif. Kaum Pentakosta meyakini bahwa pencurahan Roh Kudus di akhir zaman ditandai dengan karunia seseorang untuk berbahasa Roh. Namun sebenarnya Gerakan Pentakosta tidak hanya berdekatan dengan doktrin Roh Kudus, tetapi juga doktrin akhir zaman (eskatologi). Sebagai gerakan yang berfokus kepada pencurahan Roh Kudus di akhir zaman, eskatologi merupakan doktrin yang sangat esensial dalam Gerakan Pentakosta. Wonsuk Ma mengklaim, "Thus, Pentecostalism was born as an eschatological movement, by interpreting the outbreak of the unprecedented revival as the prerequisite for the immanent return of the Lord in their lifetime." 85 Peter Althouse berargumen bahwa eskatologi merupakan dasar utama yang melahirkan Gerakan Pentakosta dan mewarnai aspek-aspek lainnya dari doktrin Pentakosta, "Thus a major thrust of the Pentecostal

85 Wonsuk Ma, "Pentecostal Eschatology: What Happenned When the Wave Hit the West End of the Ocean," AJPS 12:1 (2009): 97. 
movement was its eschatological message, a message made real by the experiences of God's presence. Other aspects of Pentecostalism, such as its view of missions, ecclesiology, pastoral concerns, and so on, all stemmed from its eschatological vision." 86

Kedekatan Gerakan Pentakosta dengan eskatologi tidak berarti bahwa Gerakan Pentakosta membangun doktrin akhir zamannya sendiri dari nol, atau berbeda sama sekali dari kaum konservatif Protestan. Sebagaimana yang dikatakan oleh Glenn Balfour, sebetulnya tidak ada satupun posisi eskatologis Pentakosta merupakan sesuatu yang intrinsik dari gerakan itu sendiri. Balfour mengatakan, "For sure, since no one eschatological position is intrinsic to Pentecostalism, in one sense, 'Pentecostal Eschatology' does not exist."87 Masih menurut Balfour, meski Gerakan Pentakosta memiliki berbagai jenis posisi dalam eskatologi mereka, pada umumnya eskatologi Pentakosta dipengaruhi oleh dispensasionalisme, "It remains, however, that from its earliest days Pentecostalism adopted one. Ironically, perhaps, it adopted that of the Dispensationalists." 88 Sejalan dengan Balfour, Wolfgang Vondey dan Peter Althouse juga menganggap bahwa pada umumnya eskatologi Pentakosta dipengaruhi oleh dispensasionalisme, khususnya premilenialisme dispensasional. Vondey berkomentar, "The doctrinal articulation of Pentecostal eschatology emerged primarily in the context of adopting or modifying the convictions of classical dispensasionalism." 89 Althouse mengatakan, "Pentecostal generally adopted a premillennial dispensational eschatology."90

Pendapat dari beberapa ahli di atas tidak serta merta menjadikan premilenialisme dispensasional sebagai eskatologi yang paten bagi gerakan Pentakosta. Dalam perjalanan sejarah gerakan Pentakosta, didapati bahwa tidak semua kaum Pentakosta menganut premilenialisme dispensasional. Justru kenyataannya pandangan premilenialisme dispensasional ini memiliki beberapa kelemahan secara teologis, bahkan seringkali tidak cocok dengan doktrin Pentakosta secara umum. Artikel ini akan membahas apa yang menyebabkan premilenialisme dispensasional seringkali dipandang sebagai eskatologi Pentakosta secara umum, lalu penulis juga akan menjabarkan kritik-kritik dari dalam aliran Pentakosta sendiri terhadap pandangan premilenialisme dispensasional. Tujuan

\footnotetext{
86 Peter Althouse, Spirit of the Last Days: Pentecostal Eschatology in Conversation with Jurgen Moltmann (London: T\&T Clark, 2003), 10.

87 Glenn Balfour, “Pentecostal Eschatology Revisited," JEPTA Vol. 2 (2011): 128.

88 Balfour, "Pentecostal Eschatology Revisited," 128. 2017), 139.

${ }^{89}$ Wolfgang Vondey, Pentecostal Theology: Living the Full Gospel (London: Bloomsbury T\&T Clark, ${ }^{90}$ Althouse, Spirit of the Last Days, 16.
} 
dari artikel ini pada akhirnya akan mencoba mengusulkan sebuah model eskatologi yang penulis pandang mampu menjadi sebuah kerangka pikir eskatologi Pentakosta di zaman sekarang, yaitu postmilenialisme bersyarat (conditional postmillennialism).

\section{Pengaruh Dispensasionalisme Fundamental dalam Eskatologi Pentakosta Klasik}

Bapak-Bapak Pentakosta klasik, yaitu Charles Parham dan William Seymour, mendasarkan pandangan eskatologis Pentakosta awal pada konsep "hujan akhir." Istilah hujan akhir merujuk kepada nubuatan di dalam Yoel 2:28-32 yang dikutip dalam Kisah Para Rasul 2:17-21, di mana istilah ini digunakan untuk menggambarkan pencurahan Roh Kudus yang kedua setelah peristiwa Pentakosta di zaman rasul-rasul. Di Palestina, biasanya masyarakat merayakan dua kali masa hujan; hujan awal (early rain) merupakan masa hujan yang menandakan bahwa masa menanam telah dimulai, dan hujan akhir (latter rain), yang merupakan masa hujan yang menandakan bahwa ladang sudah siap dituai. Kaum Pentakosta menafsirkan masa hujan awal sebagai masa pencurahan Roh Kudus yang pertama, di mana para rasul menanam benih Injil di dunia pada abad pertama oleh kuasa Roh Kudus. Sedangkan masa hujan akhir adalah ketika Roh Kudus dicurahkan kembali kepada orang-orang percaya di akhir zaman untuk mengadakan tanda-tanda ajaib, sehingga akan membuahkan pertobatan banyak orang (tuaian besar).

Larry McQueen menulis, "Historically, then, participants at Azuza Street located themselves 'in the evening of the dispensation of Holy Ghost' (the day of Pentecost being 'the morning')."91 Pencurahan Roh Kudus yang kedua ini ditandai oleh karunia berbahasa roh yang kembali dialami oleh orang-orang percaya di masa kini sebagai tanda baptisan Roh Kudus, serta tanda-tanda ajaib seperti mujizat-mujizat dan karunia kesembuhan. Konsep hujan akhir ini kemudian menjadi bingkai bagi pandangan Pentakosta klasik mengenai eskatologi.

${ }^{91}$ Larry McQueen, "Early Pentecostal Eschatology in the Light of the Apostolic Faith," dalam Perspective in Pentecostal Eschatology: World Without End, Peter Althouse dan Robby Wadell, eds (Cambridge: James Clarke \& Co, 2012), 142. 


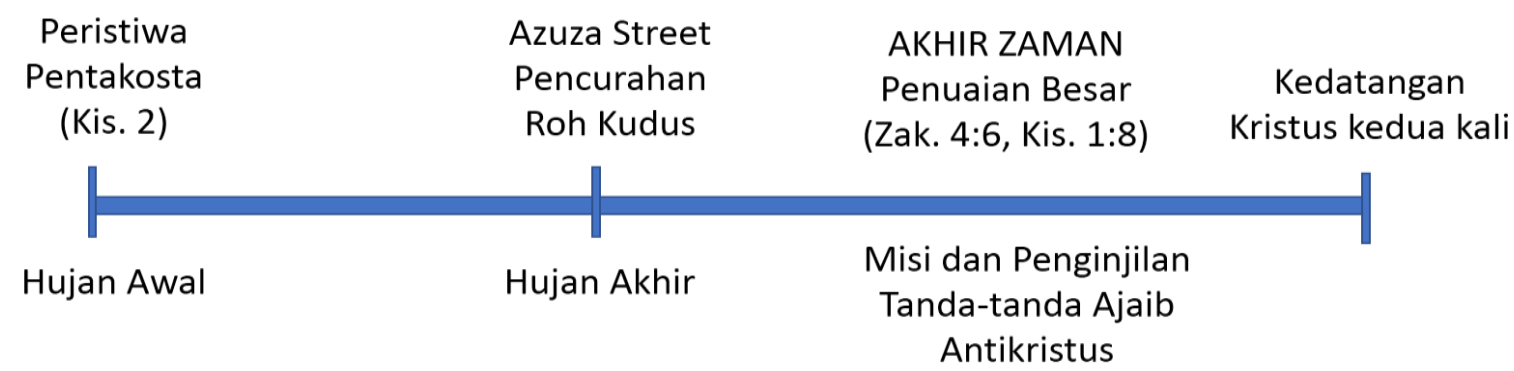

Diagram 1.1 Pandangan Pentakosta klasik tentang Eskatologi

Diagram di atas menunjukkan secara singkat pandangan eskatologi kaum Pentakosta klasik yang dikemukakan Bapak-Bapak Pentakosta. Pada masa awal ini, tampaknya belum ada pembagian secara spesifik tentang masa-masa akhir zaman seperti pengangkatan, tribulasi dan kerajaan seribu tahun. Dalam perkembangannya, pandangan Parham dan Seymour ini mendapatkan pengaruh dari pandangan dispensasional fundamentalis yang dipelopori oleh John Nelson Darby, pemimpin Plymouth Brethren dan kontributor Alkitab Scofield. Pandangan dispensasional fundamentalis ditandai dengan penafsiran harafiah yang berlaku pada semua bagian Alkitab, serta pembagianpembagian masa yang fundamental. Gerald T. Sheppard menjelaskan,

Though the exact nature of a "dispensational system" of interpretation varies somewhat, the essence of this approach turns on the advocacy of both "literal interpretation" as well as a strict separation in the literal meaning of biblical texts relating to the church from those applicable to Israel..$^{92}$

William Menzies menegaskan kuatnya pengaruh dispensasionalisme fundamental dalam gerakan Pentakosta modern. Ia mengatakan, "There is no question about the strong influence of Fundamentalism in the shaping of the values of the modem Pentecostal movement. This factor must be taken into account by those who wish to truly understand the origins of the Pentecostal movement."93 Kuatnya pengaruh dispensasionalisme fundamental dalam pandangan Pentakosta klasik menyebabkan beberapa perubahan yang signifikan dalam eskatologi Pentakosta. Perubahan yang pertama adalah dalam hal pembagian masa dalam Alkitab. Pandangan dispensasional fundamental pada umumnya membagi masa-masa dalam Alkitab menjadi tujuh bagian, yaitu:

\footnotetext{
92 Gerald T. Sheppard, "Pentecostal and the Hermeneutics of Dispensationalism: The Anatomy of an Uneasy Relationship,” Pneuma, Journal of Society for Pentecostal Studies (Fall, 1984): 5.

93 William W. Menzies, "Non-Wesleyan Pentecostalism: A Tradition, The Influence of Fundamentalism," AJPS 14:2 (2011): 211.
} 
1. Masa ketidakberdosaan - Kejatuhan manusia dalam dosa

2. Masa kesadaran - Masa air bah

3. Masa pemerintahan raja-raja - Pembuangan ke Babel

4. Masa janji pemulihan - Penawanan di Mesir

5. Masa hukum Taurat - Penolakan Kristus

6. Masa anugerah - Kedatangan Kristus kedua kali

7. Masa pemerintahan Kerajaan Kristus

Menurut Althouse, gerakan Pentakosta awal tidak menganut tujuh pembagian ini, melainkan hanya membagi zaman menjadi tiga bagian, yaitu: (1) Masa Bapa, saat-saat penantian manifestasi Kristus di dunia, (2) Masa Anak, saat penantian penggenapan janjijanji Bapa, (3) Masa Roh Kudus, masa sekarang, di mana Roh Kudus mencurahkan karunia-karunia-Nya untuk memperlengkapi gereja menyambut kedatangan Kristus kedua kali. Masa Roh Kudus ini terbagi atas hujan awal (early rain) dan hujan akhir (latter rain). Walaupun kaum Pentakosta terbuka pada dua pembagian masa ini (tujuh dan tiga masa), namun Pentakosta klasik yang dibangun oleh Parham dan Seymour lebih merujuk pada pembagian tiga masa. Althouse mengatakan, "Although early Pentecostals operated with both a threefold and sevenfold dispensational framework, particularly in Parham's theology, perhaps it is not too bold to say that early Pentecostal theology was more compatible with the threefold framework." 94 Namun karena pengaruh dispensasionalisme yang kuat dalam eskatologi Pentakosta, pembagian tujuh masa akhirnya diterima oleh sebagian besar kaum Pentakosta pada saat itu.

Perubahan yang kedua adalah mengenai pemisahan antara gereja dengan Israel secara biologis. Menurut kaum dispensasialis fundamental, pelayanan-pelayanan Yesus di dunia ini bukan tertuju pada gereja, melainkan pada bangsa Israel. Gereja hanya merupakan konsekuensi atas penolakan Israel kepada Kristus, sehingga akhirnya Tuhan juga membuka kesempatan bagi orang-orang non-Israel untuk memperoleh keselamatan. Masa gereja merujuk kepada masa parentetikal (parenthetical age) di mana masa itu adalah masa yang tidak terduga, di mana bangsa Israel menolak keselamatan dari Allah yang dinyatakan lewat Yesus Kristus. ${ }^{95}$ J.N. Darby mengatakan,

There is no earthly event between (the Church) and heaven...It is this conviction that the Church is properly heavenly, in its calling and relationship with Christ, forming no part of the course of the events (concerning Jews) of the earth which

\footnotetext{
${ }_{94}$ Althouse, Spirit of the Last Days, 43.

95 Sheppard, "Pentecostal and the Hermeneutics of Dispensationalism," 7.
} 
makes its (pretribulational) rapture so simple and clear; and, on the other hand, it shows how the denial of its rapture brings down the church to an earthly position and destroys its whole spiritual character and position. ${ }^{96}$

Meskipun terdapat beberapa perbedaan pandangan, pengaruh dispensasionalisme fundamental tidak terelakkan dalam perkembangan gerakan Pentakosta setelahnya, khususnya dalam Gereja Sidang Jemaat Allah (Assembly of God). Pada tahun 1914, gereja tersebut mengeluarkan sebuah pernyataan iman yang disebut Statement of Fundamental Truths di Hot Spring, Arkansas. Dalam dua poin pernyataan imannya tersebut, Gereja Sidang Jemaat Allah menampakkan paham eskatologis yang sudah bergeser dari paham Pentakosta klasik ke paham dispensasionalisme fundamental. Dua pernyataan tersebut dicatat sebagai berikut,

THE BLESSED HOPE

The resurrection of those who have fallen asleep in Christ and their translation together with those who are alive and remain unto the coming of the Lord is the imminent and blessed hope of the Church. 1 Thess. 4:16,17; Romans 8:23; Titus 2:18; 1 Cor. 15:51,52.

THE MILLENNIAL REIGN OF JESUS

The revelation of the Lord Jesus Christ from heaven, the salvation of national Israel, and the millennial reign of Christ on earth are the Scriptural promises and the world's hope. 2 Thess. 1:7; Rev. 19:11-14; Romans 11:26,27; Rev. 20:17.

Walaupun tidak secara literal mendukung pandangan premilenialisme dispensasional, dua pernyataan ini menunjukkan bahwa eskatologi Pentakosta klasik telah mengalami beberapa pergeseran. Secara khusus pengaruh dispensasional fundamental dalam eskatologi Pentakosta tampak pada munculnya pengajaran mengenai pengangkatan gereja (secret rapture), masa tribulasi, dan kerajaan seribu tahun. Pengangkatan ditempatkan sebelum masa tribulasi dan hanya terjadi kepada gereja, tidak terjadi pada bangsa Israel. Pada saat pengangkatan, Yesus datang di awan-awan dan gereja akan terangkat menyambut Yesus di awan-awan. Sementara orang-orang yang tidak percaya akan tertinggal di bumi ini, termasuk bangsa Israel, untuk mengalami masa tribulasi. Setelah mengalami masa tribulasi, gereja turun untuk memerintah bersama bangsa Israel di bumi selama seribu tahun.

Di akhir kerajaan seribu tahun, akan ada penyesatan terakhir dari Antikristus, yang akan diakhir dengan Perang Armageddon yang menyebabkan kehancuran bumi.

96 J.N. Darby, "The Rapture of the Saints," Collected Writings, Vol. 2, 237-238. 
Setelah itu, terjadi kedatangan Kristus yang kedua kali. Bala tentara Iblis akan dikalahkan dan dimasukkan dalam Neraka, sementara orang-orang pilihan Allah akan masuk ke Sorga (Langit Baru Bumi Baru). Pandangan ini disebut sebagai premilenialisme dispensasional. Disebut premilenialisme karena mempercayai kedatangan Kristus mendahului kerajaan seribu tahun, dan dispensasionalis karena cara penafsirannya yang literal terhadap Alkitab, khususnya mengenai akhir zaman. Kaum Pentakosta akhirnya mengadopsi doktrin ini menjadi bagian dalam diagram eskatologisnya.

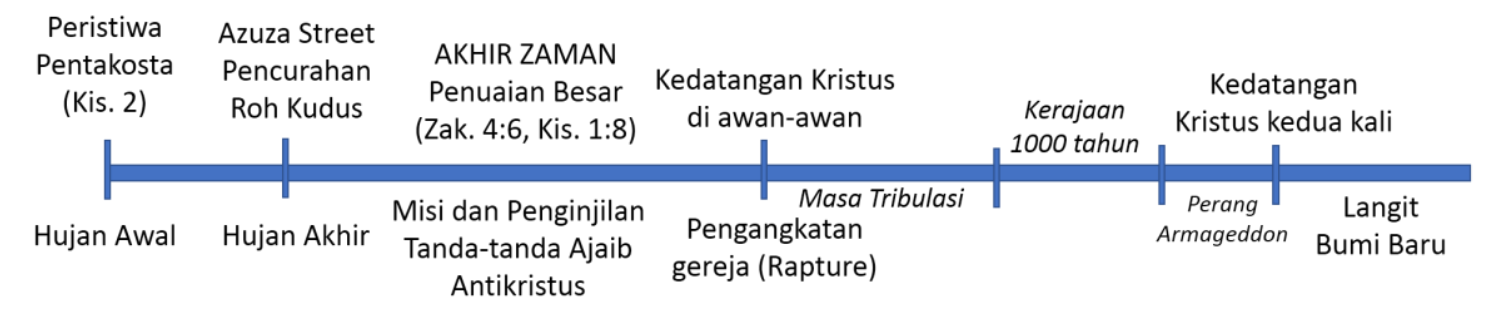

Diagram 1.2 Pengaruh dispensasionalisme fundamental terhadap kerangka eskatologis Pentakosta klasik

Pengaruh dispensasionalisme fundamental dalam kerangka eskatologi Pentakosta terus berlanjut sampai masa kini. Mayoritas kaum Pentakosta modern menganut pandangan premilenialisme dispensasional. Secara garis besar Glen Balfour menyimpulkan tiga ciri umum pandangan eskatologi Pentakosta modern: 1. Akhir zaman bersifat futuris (Imminent futurist eschatology), 2. Premillennialisme, dan 3. Pentingnya bangsa Israel dalam pandangan eskatologis mereka (Significance of the nation of Israel). ${ }^{97}$

Menurut Balfour, kaum Pentakosta menganggap bahwa akhir zaman selalu bersifat futuris, yang akan terjadi di waktu-waktu mendatang yang tidak jauh dari waktu mereka hidup. Berbeda dengan aliran tradisional, sebut saja aliran Reformed, yang mempercayai bahwa akhir zaman sudah terjadi sejak zaman Kristus naik ke surga sampai kedatangannya yang kedua kali (already but not yet), kaum Pentakosta menganggap akhir zaman dan tanda-tandanya baru akan terjadi di depan mereka (not yet). Tafsiran kaum Pentakosta juga tidak lepas dari premilenialisme, dalam arti kaum Pentakosta mempercayai kedatangan Kristus yang kedua akan mengawali masa seribu tahun. Pandangan ini juga meliputi kepercayaan mereka akan adanya pengangkatan sehingga gereja tidak perlu menghadapi masa tribulasi. Ketiga, pandangan Pentakosta masa kini

${ }^{97}$ Balfour, “Pentecostal Eschatology Revisited," 129. 
yang dipengaruhi oleh dispensasionalisme fundamental tentu saja sangat mementingkan posisi bangsa Israel dalam teologinya. Hal ini disebabkan kaum Pentakosta membedakan antara Israel sebagai suatu bangsa pilihan Allah dan gereja, sebagai akibat dari penolakan Israel (parenthesis). Namun menurut Balfour, keadaan pasca Holocaust yang bersifat anti-semitic juga banyak mempengaruhi penerimaan atas doktrin kepentingan bangsa Israel ini, khususnya aliran Pentakosta di Amerika Utara dan Eropa. ${ }^{98}$

Kesimpulannya, meski berbeda jauh dari pandangan Bapak-Bapak Pentakosta klasik, dapat dikatakan banyak kaum Pentakosta zaman sekarang yang memegang pandangan premilenialisme dispensasional seperti yang tertera di diagram 1.2. Bahkan, pandangan ini telah dijadikan sebagai pandangan kaum Pentakosta secara umum di masa kini. Sheppard mengatakan, "In sum, in several cases, a more consistent dispensational eschatology has led later Pentecostals to a more consistently dispensational ecclesiology... These changes are at present ad hoc and lack full consensus."99 Sejalan dengan itu, Amos Yong menulis, "Many early modern Pentecostals were certainly premillennialists, although there were also wide-ranging differences and emphases across the movement... Dispensationalist premillennialism has become popularized over the course of the twentieth century, in part due to the turmoil and upheaval of the last hundred years but also in part in anticipation of the end of the second millennium."100 Perubahan ini juga terbukti dengan publikasi beberapa buku dan film rohani oleh kaum Pentakosta modern yang mendukung pandangan pretribulasi dan dispensasionalisme fundamental, seperti Late Great Planet Earth oleh Hal Lindsey (1970), novel Left Behind (1998) yang menjadi Best Seller dalam New York Times dan bahkan sudah difilmkan dan seringkali diputar di gereja-gereja untuk menggambarkan akhir zaman.

\section{Kritik terhadap Eskatologi Premilenialisme-Dispensasional Pentakosta}

Perkembangan eskatologi Pentakosta menjadi premilenialisme dispensasional mendatangkan kritik bagi pandangan ini, bahkan dari dalam kalangan Pentakosta sendiri. Kritik yang paling utama adalah bahwa pandangan eskatologi premilenialisme dispensasional, yang telah banyak dipengaruhi oleh dispensasionalisme fundamental,

98 Balfour, "Pentecostal Eschatology Revisited," 132.

${ }^{99}$ Sheppard, "Pentecostal and the Hermeneutics of Dispensationalism," 26.

100 Amos Yong, Renewing Christian Theology: Systematic for a Global Christianity (Texas: Baylor University Press, 2014), e-book, bab 2.2. 
sama sekali tidak sejalan dengan teologi Pentakosta, bahkan juga tidak sejalan dengan Alkitab sendiri. Ada beberapa alasan yang memunculkan pemikiran ini.

Pertama, teologi Pentakosta klasik tidak pernah menekankan adanya pemisahan antara gereja dengan Israel. Menurut John A. Bertone, premilenialisme dispensasional menekankan pemisahan gereja dan Israel sehingga mengakibatkan munculnya doktrin pengangkatan gereja dan kerajaan seribu tahun, doktrin-doktrin yang dianggap tidak pernah diajarkan oleh Bapak-Bapak Pentakosta, bahkan oleh Rasul Paulus sendiri. Rasul Paulus tidak pernah membedakan antara Israel jasmaniah dan gereja, walaupun di satu sisi Paulus juga pernah membedakan antara orang Yahudi dan orang non-Yahudi dalam surat-suratnya. Namun pembedaan ini tidak berarti bahwa Allah membedakan keadaan eskatologis bangsa Israel dan gereja. Bahkan Rasul Paulus menyatakan bahwa berkatberkat untuk Israel pun berhak dinikmati oleh gereja (Gal. 3:6-9). Ketika berbicara soal "Israel," khususnya dalam konteks keselamatan, jelas Paulus sedang merujuk kepada semua orang percaya, yang disebut Bertone sebagai "Israel as a corporate identity is meant." ${ }^{101}$ Sejalan dengan itu, McQueen berargumen bahwa dalam eskatologi Pentakosta, "the church was not defined in terms of its distinction from Israel but was seen as the group from which the bride of Christ would emerge."102 Israel yang dimaksud dalam Perjanjian Baru adalah mempelai Kristus, sebagaimana kaum Pentakosta awal di Azuza Street menggambarkan diri mereka.

Teologi Pentakosta juga tidak menafsirkan nubuatan Yoel dalam Kisah Para Rasul pasal 2 sebagaimana dispensasionalisme fundamental menafsirkan ayat tersebut. Dispensasionalisme fundamental menafsirkan bahwa nubuatan Yoel tertuju untuk pemulihan bangsa Israel. Di sisi lain kaum Pentakosta menafsirkan bahwa nubuatan itu tertuju pada gereja di akhir zaman, di mana nubuatan itu sendiri sedang berbicara mengenai terulangnya kembali karunia berbahasa roh dalam gereja Pentakosta. Jikalau nubuatan Yoel hanya berlaku untuk bangsa Israel maka berarti pengalaman Pentakosta tidaklah berarti apa-apa, dan berarti pandangan Bapak-Bapak Pentakosta mengenai hujan akhir tidaklah benar. Lagipula, pandangan dispensasionalis fundamental ternyata juga menolak karunia-karunia Roh masih terjadi di zaman sekarang, salah satu yang terpenting adalah mereka menolak karunia berbahasa roh masih berlangsung sampai

101 John A. Bertone, "Seven Dispensations or Two-Age View of History," dalam Perspective in Pentecostal Eschatology: World Without End, Peter Althouse dan Robby Wadell, eds (Cambridge: James Clarke \& Co, 2012), 73.

102 McQueen, "Early Pentecostal Eschatology," 153. 
zaman sekarang. Di dalam versi Alkitab J.N. Darby, Scofield Bible, tersurat bahwa pandangan dispensasionalis memegang pandangan cessasionis, yang mempercayai bahwa karunia-karunia roh sudah berhenti di zaman rasul-rasul. Tentu ini sangat bertentangan dengan esensi pandangan kaum Pentakosta. Althouse berkata,

While Pentecostalism may have had some affinity to premillennial dispensationalism, its cessasionist assumptions severely undercut Pentecostal pneumatology and ecclesiology... In other words, dispensationalism created a serious threat to the Pentecostal insistence that the apostolic gifts were for today's church. ${ }^{103}$

Oleh sebab itu makin jelas bahwa sebenarnya ajaran dispensasional fundamentalis tidak sesuai dengan kerangka eskatologis Pentakosta.

Kedua, doktrin pengangkatan, tribulasi, dan kerajaan seribu tahun merupakan ajaran yang tidak sesuai dengan Alkitab maupun doktrin Pentakosta. Bertone mengatakan, "As we shall argue, the notion of a separate 'rapture' of the church followed by an interval of seven years before the Second Coming and millennial reign of Christ was foreign to Paul."104 Bertone berargumen bahwa ajaran pengangkatan, masa tribulasi, dan kerajaan seribu tahun ini hanya berasal dari ajaran J.N. Darby yang salah. J.N. Darby, pelopor ajaran dispensasionalisme fundamental, mendengar seorang jemaat di Glasgow yang bernama Margaret MacDonald mendapatkan penglihatan soal kedatangan Kristus di dalam dua peristiwa yang berbeda (saat pengangkatan dan pasca kerajaan seribu tahun). Kemudian, menurut Bertone, "Darby used Paul's discussion of the Parousia in I Tes. 4-5 to substantiate this theological position."105

Doktrin pengangkatan, tribulasi, dan kerajaan seribu tahun ini juga tidak sejalan degan teologi Pentakosta, yang pada awalnya dan masih sampai sekarang berfokus kepada harapan akan kedatangan Kristus yang kedua sebagai sebuah hal yang menggairahkan, dan bukan sesuatu yang menakutkan. Pengajaran mengenai masa tribulasi menyebabkan pengharapan akan kedatangan Kristus bukan pengharapan yang menggairahkan seperti semangat Pentakosta awal, melainkan sebagai sesuatu yang mencekam. Pengharapan akan datangnya Kristus berganti dengan pertanyaan: “Apakah saya akan diangkat?" Sheppard berargumen,

103 Peter Althouse, "Pentecostal Eschatology in Context: The Eschatological Orientation of the Full Gospel," dalam Perspective in Pentecostal Eschatology: World Without End, Peter Althouse dan Robby Wadell, eds (Cambridge: James Clarke \& Co, 2012), 207-208.

104 Bertone, "Seven Dispensations or Two-Age View of History," 74.

105 Bertone, "Seven Dispensations or Two-Age View of History," 75. 
Certainly, Pentecostals, who look to Azusa Street as their galvanizing moment in history, do not find that all of the leading figures taught pre-tribulation rapture. For Pentecostals the emphasis on eschatology belonged more naturally to the sense of a final glorious revelation and outpouring of the Spirit in the last days, than, as with fundamentalists, to the dark prospect of impending destruction for those not suddenly taken out of this world.

Ketiga, jika pandangan premilenialisme dispensasional masih mewarnai eskatologi Pentakosta, maka eskatologi Pentakosta akan selalu bertentangan dengan perkembangan ilmu pengetahuan, politik, dan budaya di dunia ini. Sulit bagi premilenialis dispensasional untuk mengadakan diskursus antara iman dan ilmu (faith and learning), sebagaimana yang dikemukakan Rick Langer, "This rich, varied and sustained conversation on faith and learning simply has no counterpart in the dispensational community."106 Menurut Langer, ada dua alasan mengapa eskatologi ala premilenialisme dispensasionalis sulit untuk menerima perkembangan ilmu pengetahuan. Alasan pertama, keyakinan para dispensasionalis bahwa Israel berbeda dengan gereja membuat mereka percaya bahwa tugas untuk mengembangkan ilmu pengetahuan di bumi ini adalah tugas Israel, dan bukan tugas gereja. Pasalnya, gereja dirujuk sebagai komunitas sorgawi, sedangkan Israel adalah komunitas yang harus menguasai dan memimpin bumi. Langer menjelaskan, "Therefore, engaging human culture, government, art and agriculture is Israel's concern and not the church's. Engaging and shaping earthly culture is not the job of God's heavenly people."107

Alasan kedua berhubungan dengan pandangan mereka yang bersifat futuris dalam eskatologi. Pandangan futuris menganggap bahwa akhir zaman dan tanda-tandanya belum terjadi di dunia sekarang ini (not yet), oleh sebab itu setiap perkembangan zaman selalu dicurigai sebagai Antikristus dan jahat, yang merupakan tanda-tanda akhir zaman. Contohnya ketika teknologi chip mulai berkembang, banyak sekali teolog-teolog Pentakosta yang menolak teknologi tersebut karena dianggap sebagai lambang Antikristus. Juga mereka mempercayai bahwa bumi bukanlah sesuatu yang harus dipertahankan karena nantinya akan dihancurkan di akhir zaman. Oleh sebab itu, perkembangan ilmu pengetahuan juga merupakan hal yang tidak penting bagi komunitas sorgawi seperti gereja. Menurut McQueen, tafsiran dispensasional fundamentalis yang

106 Rick Langer, "Kingdom Integration: Reflections on Premillennialism and Cultural Engagement," CTR 10/1 (Fall 2012), 23.

107 Langer, "Kingdom Integration," 24. 
futuris terhadap Alkitab ini juga tidak cocok dengan hermeneutika Pentakosta. Ia mengatakan,

First, the Old Testament was not compartmentalized but was viewed as a rich source of texts that "typified" early Pentecostal soteriology and eschatology. Second, the images in the book of Revelation were not relegated to the future, but had contemporary importance for the spirituality of the believer. ${ }^{108}$

Keempat, keyakinan premilenialisme dispensasional bahwa bumi akan dihancurkan di akhir zaman juga membuat kaum Pentakosta yang menganut pandangan ini tidak mempedulikan akan ekologi dan kesejahteraan alam. Jeffrey S. Lamp mengatakan,

It is noteworthy that virtually all of the present-day Pentecostals who argue for creation care as a valid expression of life in the Spirit are also critical of the dispensational eschatology that is so closely aligned with lack of concern for environmental issues, whether among Pentecostals or non-Pentecostals. ${ }^{109}$

Sebaliknya, kaum Pentakosta cenderung lebih menekankan penginjilan daripada memelihara ekosistem, karena mereka berpikir bahwa penginjilan lebih penting daripada penjagaan alam. Alam akan dihancurkan Tuhan di akhir zaman, sedangkan jiwa manusia akan menemui nasib kekalnya, entah ke Surga atau ke Neraka. Kärkäinen menulis, "Now, there is no denying the fact that in the formative years of the movement many Pentecostals' eschatological fervor blurred the meaning of social improvement. Why invest in a world that was believed will fade away?"110 Lamp menambahkan,

A more colloquial way of expressing this is to say that since God, in the end, is only going to destroy the world in judgment, the most important work of the church in the world is to save the souls of sinners. In this view, works aimed at such things as creation care are viewed as less important than evangelism. ${ }^{111}$

Walaupun memang penginjilan adalah hal yang penting dalam teologi Pentakosta, namun tidak berarti bahwa hal yang lain menjadi diabaikan, termasuk pemeliharaan alam.

Selain tidak peduli akan pemeliharaan alam, kaum premilenialis dispensasional juga tidak peduli terhadap aksi-aksi sosial. Pandangan mereka terhadap dunia cenderung pesimis, dan meyakini bahwa semakin hari dunia ini akan semakin memburuk. Puncaknya, dunia akan hancur saat Kristus datang, bahkan Kristus sendirilah yang akan

\footnotetext{
108 McQueen, "Early Pentecostal Eschatology," 153.

109 Jeffrey S. Lamp, "New Heavens and New Earth: Early Pentecostal Soteriology as a Foundation for Creation Care in the Present," Pneuma 36 (2014): 78.

110 Veli Matti Kärkäinen, "Truth on Fire: Pentecostal Theology of Mission and the Challenges of a New Millenium," AJPS 3/1 (2000): 48.

111 Lamp, "New Heavens and New Earth," 66.
} 
menganihilasi dunia ini. Oleh sebab itu aksi-aksi sosial juga dianggap sebagai sesuatu yang tidak signifikan dalam pandangan eskatologi premilenialisme dispensasional. Namun uniknya, dalam praktek pelayanan kaum Pentakosta, justru mereka sangat aktif dalam aksi-aksi sosial. Murray W. Dempster menjelaskan,

But while this eschatologically-driven indifference to social change, as Wilson describes it, typified the Pentecostal attitude towards the social world, it did not hold all Pentecostal leaders captive. From the beginning of the movement, a sprinkling of ministers involved the church in social work. Some church leaders on tire home front established orphanages and hospices. A few missionaries overseas built rescue homes and lepersariums out of compassionate concern for the homeless and for those who were viewed as the outcasts of society. ${ }^{112}$

Tentu saja praktek di lapangan ini menunjukkan bahwa semangat Pentakosta sesungguhnya bukanlah semangat bahwa bumi akan dihancurkan ataupun pesimisme terhadap perbaikan dunia ini. Ini menunjukkan bahwa sebenarnya semangat Pentakosta sangat jauh berbeda dengan apa yang diajarkan oleh premilenialisme dispensasional.

Dengan beberapa kritik di atas, dapat dikatakan bahwa eskatologi Pentakosta yang bersifat premilenialisme dispensasional menemui banyak hal yang tidak sesuai dengan teologi Pentakosta, dan dikritik oleh banyak teolog Pentakosta sendiri. Kärkäinen menegaskan bahwa dispensasionalisme fundamental dan Pentakosta adalah dua hal yang tidak mungkin dipersatukan, "The marriage between Pentecostals and dispensational theology has been odd indeed, and certainly not without tensions."113 Pengaruh dispensasionalisme fundamental membuat Pentakosta kehilangan identitas yang sebenarnya. Oleh sebab itu, selanjutnya penulis akan mengusulkan sebuah model eskatologi yang lebih sesuai dengan teologi Pentakosta.

\section{Postmilenialisme Bersyarat:}

\section{Sebuah Usulan Model Eskatologi Pentakosta}

\section{Postmilenialisme: Telaah Teologis}

Setelah menjabarkan sejarah eskatologi Pentakosta dari Bapak-Bapak Pentakosta sampai pengaruh premilenialisme dispensasional, juga menjabarkan kritik-kritik dari para teolog Pentakosta mengenai hal tersebut, penulis tertarik untuk mengajukan sebuah

112 Murray W. Dempster, “Christian Social Concern in Pentecostal Perspective: Reformulating Pentecostal Eschatology," Journal of Pentecostal Theology 2 (1993): 52.

113 Kärkäinen, "Truth on Fire," 49. 
model eskatologi yang khas Pentakosta tetapi tidak bertentangan dengan Alkitab dan juga teologi Pentakosta klasik selama ini. Model eskatologi Pentakosta ini harus memenuhi ciri-ciri sebagai berikut:

1. Khas pentakosta, dalam arti memiliki ciri khas hujan akhir sebagaimana yang ditegaskan oleh para pemimpin gerakan Pentakosta klasik. Eskatologi Pentakosta harus merupakan sebuah gairah akan penuaian jiwa-jiwa di akhir zaman dan kedatangan Kristus kedua kali.

2. Sesuai dengan Alkitab, bukan dibangun berdasarkan pengalaman-pengalaman subyektif seseorang dan tafsiran yang tidak sesuai dengan kaidah yang berlaku, sebagaimana yang dilakukan Darby dalam kasus Margaret MacDonald.

3. Menolak pemisahan antara Israel dengan gereja sebagai dua entitas yang terpisah.

4. Tidak menentang perkembangan ilmu pengetahuan, aksi-aksi sosial, dan pemeliharaan lingkungan

Menurut penulis, untuk memenuhi syarat-syarat ini, eskatologi Pentakosta harus dilepaskan dari pemahaman dispensasionalisme fundamental, bahkan jika boleh dikatakan, dilepaskan sepenuhnya dari pengaruh tersebut. Sebab dispensasionalisme fundamental sama sekali tidak memenuhi satupun dari lima syarat di atas. Seperti yang sudah dijelaskan sebelumnya, dispensasionalisme fundamental bersifat cessasionist dan bercirikan ketakutan, tidak sesuai dengan Alkitab, memisahkan Israel dan gereja, menentang perkembangan ilmu, dan juga cenderung mengabaikan bumi yang sekarang. Oleh sebab itu model ini tidak dapat diterapkan sebagai eskatologi Pentakosta.

Lalu eskatologi seperti apa yang cocok dengan teologi Pentakosta? Larry McQueen menemukan bahwa sebenarnya ketika dispensasionalisme fundamental mulai mempengaruhi pandangan Pentakosta klasik, sebenarnya ada aliran yang masih mengikuti dan sejalan dengan pandangan Pentakosta klasik, namun tidak terpengaruh oleh dispensasionalisme fundamental.114 Pandangan tersebut adalah Gerakan Kekudusan Wesleyan. Lamp menuliskan, “Moreover, the Wesleyan Holiness stream was far more inclined toward integrating the dynamic spirituality and core beliefs and practices of Pentecostalism into eschatology, which resulted in eschatological formulations that were themselves dynamic and tended to move away from the classical dispensational position."115 Posisi Gerakan Kekudusan Wesleyan di sini merupakan postmilenialisme. Menzies

114 McQueen, "Early Pentecostal Eschatology," 139-154.

115 Lamp, "New Heavens and New Earth," 77. 
mengatakan, "It is significant at this juncture to remind ourselves that Wesley, along with most other conservative. Evangelical Christians of that era, was a post-millennialist."116

Secara singkat, postmilenialisme adalah pandangan tentang akhir zaman yang meyakini bahwa Yesus Kristus akan datang setelah masa kerajaan seribu tahun. Namun kerajaan seribu tahun dalam pandangan postmilenial bukanlah sebuah kerajaan atau dunia yang terpisah dari bumi yang sekarang ini. Kerajaan itu adalah pemerintahan Kristus dalam hati manusia yang percaya kepada Kristus saat ini. ${ }^{117}$ Dengan kata lain, Kristus memerintah lewat gereja-Nya, dan hal itu sudah berlangsung saat ini.

Postmilenialisme tidak menafsirkan seribu tahun secara harafiah, melainkan mereka berpendapat bahwa masa seribu tahun menggambarkan sebuah masa yang panjang, di mana gereja dan kekristenan ada di masa keemasan. Titik awal dari masa seribu tahun sendiri sulit dideteksi, namun dapat dirasakan dari tanda-tandanya. Salah satu tanda terjadinya masa milenial adalah penginjilan dan pertobatan besar-besaran di seluruh dunia. Namun semua itu tidak terjadi hanya dalam sekejap mata. Seperti dikatakan Ericson, "Kerajaan itu akan tiba secara bertahap."118 Hoekema menjelaskan, "Pada waktu milenium itu terwujud, maka prinsip-prinsip iman dan moral Kristen akan diterima sebagai standar bagi semua bangsa dan individu. Dosa belum akan dihapuskan, tetapi akan dikurangi seminimal mungkin. Kehidupan sosial, ekonomi, politik, dan kebudayaan umat manusia akan mengalami perbaikan secara menyeluruh." 119 Tidak seperti premilenialisme, postmilenialisme tidak mempercayai adanya masa tribulasi sebelum kedatangan Kristus yang kedua. Menurut mereka, masa-masa kesusahan dan murtad sudah berlalu. Saat ini adalah masa keemasan gereja, yang akan memenuhi puncaknya saat Yesus datang kedua kali.

Pandangan post-milenialisme, sebagaimana yang dijelaskan Loraine Boettner, dapat didefinisikan sebagai berikut,

Kami mendefinisikan postmilenialisme sebagai pandangan tentang hal-hal akhir zaman, yang mempercayai bahwa Kerajaan Allah sekarang ini sedang terus diperluas melalui pemberitaan Injil dan pekerjaan Roh Kudus di dalam hati orangorang, sehingga seluruh dunia pada akhirnya akan dikristenkan, dan setelah itu Kristus akan kembali di penutupan masa penuh kebenaran dan damai yang Panjang, yang disebut sebagai Milenium. Patut ditambahkan bahwa menurut

116 Menzies, “Non-Wesleyan Pentecostalism,” 207.

117 Millard J. Erickson, Pandangan Kontemporer dalam Eskatologi: Sebuah Studi tentang Milenium (Malang: Literatur SAAT, 2009), 63.

118 Erickson, Pandangan Kontemporer dalam Eskatologi, 65.

${ }^{119}$ Anthony Hoekema, Alkitab dan Akhir Zaman (Surabaya: Momentum, 2000), 238. 
prinsip-prinsip postmilenialisme, kedatangan Kristus yang kedua kali akan segera diikuti dengan kebangkitan dan penghakiman atas seluruh umat manusia, serta penyataan sorga dan neraka secara penuh. ${ }^{120}$

Selanjutnya kita akan melihat apakah pandangan eskatologis postmilenialisme lebih cocok dengan teologi Pentakosta daripada premilenialisme dispensasional? Syarat pertama adalah postmilenialisme tidak boleh bertentangan dengan pandangan Pentakosta soal hujan akhir. Sejalan dengan pandangan Pentakosta soal hujan akhir, postmilenialisme juga meyakini bahwa di akhir zaman akan terjadi penginjilan besarbesaran dan menghasilkan tuaian besar, yaitu pertobatan yang besar-besaran pula. Pandangan Pentakosta cenderung optimis dalam memandang masa depan, di mana walaupun kejahatan masih ada, tapi kuasa yang diberikan Allah pada gereja lebih besar dari kejahatan yang ada. Postmilenialisme juga mempercayai bahwa masa kesusahan dan kemurtadan merupakan masa yang sudah berlalu, sedangkan penginjilan dan pertobatan menandai mulainya millennium, ini sejalan dengan pandangan Pentakosta di mana hujan akhir memiliki tanda yang sama dengan masa millennium. Postmilenialisme juga mempercayai bahwa Yesus akan datang kembali jikalau gereja telah memenuhi tugasnya menginjil sampai ke seluruh bumi. Dengan demikian, peran gereja untuk menginjil sangat signifikan bagi terjadinya kedatangan Kristus kedua kali. Hal ini juga sejalan dengan semangat Pentakosta yang mengedepankan dorongan untuk menginjil, walaupun di sisi lain tidak menyangkali karya Roh Kudus dalam penginjilan.

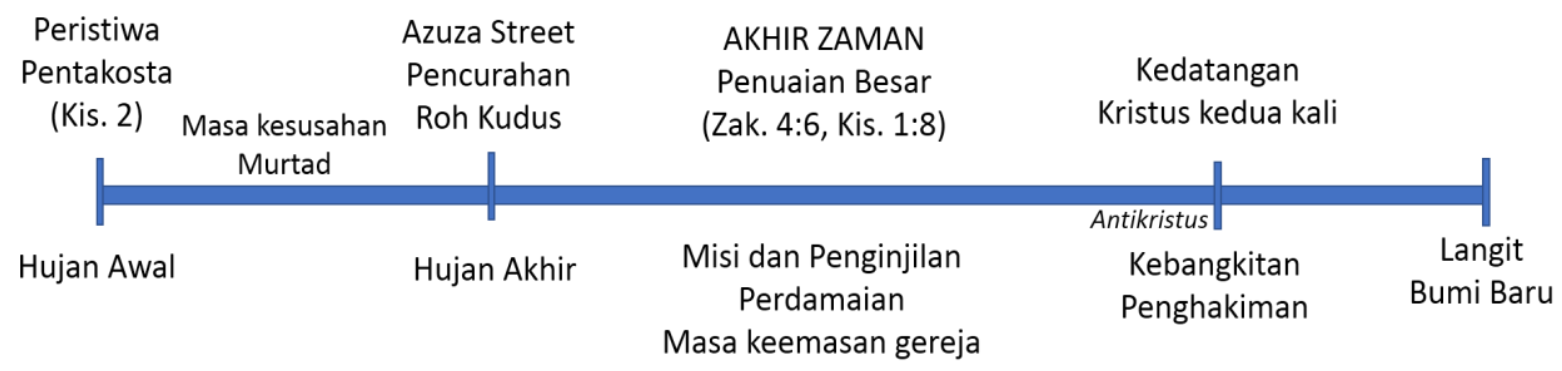

Diagram 3.1. Pandangan Postmilenialisme dalam diagram eskatologi Pentakosta

Syarat kedua apakah pandangan postmilenialisme didasarkan atas penafsiran Alkitab dan bukan pengalaman subyektif seseorang? Penganut postmilenialisme

120 Loraine Boettner, The Millenium (Grand Rapids: Baker, 1958), 14, dikutip dalam Hoekema, Alkitab dan Akhir Zaman, 238. 
mengambil dan menafsirkan beberapa ayat sebagai rujukan pandangan mereka, antara lain:

1. Penginjilan dan pertobatan besar-besaran (Roma 11:25-26)

2. Kuasa Iblis muncul di akhir milenium namun sangat terbatas (Wahyu 20:7-10)

3. Pemerintahan Gereja (Mat. 16:18)

4. Pemerintahan Mesias yang universal (Bil. 14:21, Mzm. 2:8, 22:27-29, Yes. 2:24, 11:6-9, 65-66, Yer. 31:31-34, Zak. 9:9)

5. Penebusan Kristus meliputi penebusan kosmis, bukan hanya manusia (Yoh. 3:16-17, bdk. Why. 11:15).

Selain itu, pandangan postmilenialisme telah melewati penelaahan teolog-teolog besar secara historis. Dari zaman bapak-bapak gereja awal, postmilenialisme telah menjadi sebuah pandangan eskatologis yang meyakinkan. Pada masa itu, St. Agustinus sendiri menganggap bahwa gereja telah berada pada masa millennium, karena pada masa itu gereja Katolik berkembang dengan pesat di bawah pemerintahan Kaisar Constantine, bahkan gereja memasuki ranah politik dari kerajaan itu. Pada zaman pertengahan, postmilenialisme pun masih dianut, bahkan beberapa denominasi utama seperti kaum Reformed, Lutheran, dan Presbyterian memasukkan postmilenialisme dalam pengakuan iman mereka, contohnya dalam Pengakuan Iman Westminster maupun Augsburg. ${ }^{121}$ Menurut Ericson, kalaupun saat ini penganut dari postmilenialisme mengalami kemerosotan tajam, "sebagian besar dari hal ini lebih diakibatkan oleh pertimbanganpertimbangan historis dan bukan penafsiran."122 Dari penelahaan historis terhadap postmilenialisme di atas, dapat dilihat bahwa pandangan ini tidak didasarkan pada penafsiran yang sepihak atau dibuat-buat, melainkan terbukti dalam perkembangan zaman bahwa penafsiran postmilenialisme, walau tidak dapat saya katakan sebagai yang paling benar, tidak bertentangan dengan kaidah-kaidah umum penafsiran.

Ketiga, mengenai isu gereja dan Israel. Bagaimana postmilenialisme memandang Israel? Postmilenialisme sendiri tidak pernah memisahkan gereja dan Israel sebagai dua entitas yang berbeda. Namun perlu diakui bahwa ada beberapa penganut aliran postmilenialis yang meyakini bahwa di masa milenium bangsa Yahudi akan bertobat. Namun keyakinan ini tidak sama dengan apa yang diajarkan premilenialis. Erickson menjelaskan,

121 Erickson, Pandangan Kontemporer dalam Eskatologi, 71.

122 Erickson, Pandangan Kontemporer dalam Eskatologi, 72. 
Ini bukan gagasan yang diajarkan oleh beberapa penganut premileniarisme bahwa perjanjian Allah pada dasarnya dilakukan dengan orang-orang Yahudi dan bahwa setelah suatu masa dalam menghadapi gereja, Allah akan mengembalikan bangsa Israel pada posisi atau kedudukannya yang khusus dan disayangi. Sebaiknya, hal ini lebih merupakan keyakinan bahwa nubuat-nubuat tertentu masih harus dipenuhi, yaitu bahwa sejumlah besar orang Yahudi akan bertobat dan akan memasuki gereja dengan cara yang sama seperti orang-orang percaya pada saat ini. ${ }^{123}$

Keempat, pandangan postmilenialisme pasti tidak bertentangan dengan perkembangan ilmu pengetahuan, budaya, aksi-aksi sosial dan pemeliharaan alam. Hal ini disebabkan karena postmilenialisme tidak menganut pandangan eskatologi futuris sebagaimana kaum premilenialis dispensasional. Sebaliknya, postmilenialis meyakini bahwa Kerajaan Allah merupakan realitas yang sudah ada saat ini (already) dan bukan sesuatu yang akan datang. Kerajaan itu juga akan makin jelas kedatangannya, yang secara bertahap menuju kepenuhannya saat Kristus datang kedua kali (not yet). Kedua sisi, sudah (already) dan belum tergenapi (not yet), membuat pandangan postmileniarisme sangat optimis terhadap perkembangan zaman. Bahkan mereka mendorong umat percaya untuk terus mengembangkan ilmu pengetahuan, sosial, budaya, bahkan pemeliharaan alam, sebab mereka yakin bahwa gerejalah yang harus memerintah semua aspek dalam masa millennium.

Postmilenialisme juga mempercayai bahwa pada akhirnya akan terjadi perdamaian di dunia ini. Erickson menjelaskan,

Konflik antar bangsa bukan hanya akan berhenti, melainkan juga perpecahan antar golongan dan ras sosial. Perselisihan buruh barangkali akan berakhir. Konflik rasial akan berhenti, melebur ke dalam keharmonisan antara orang-orang kulit putih, hitam, indian, Chicanos, dan lain-lain. Bahkan pergolakan agama dan kompetisi antar denominasi akan berlalu. Ini merupakan penggenapan nubuat bahwa serigala dan domba akan berbaring bersama-sama. ${ }^{124}$

Hal ini sejalan dengan apa yang dilakukan oleh kaum Pentakosta untuk menyatakan Kerajaan Allah di dunia ini. Banyak misi mereka bersifat sosial dan anti-penindasan. Bahkan dari bapa-bapa Pentakosta sendiri, hal ini sudah dipraktekkan. Charles F. Parham membangun Bethel Healing Home pada tahun 1898 di Topeka, Kansas dan mengadakan misi untuk menolong para tuna Susila dan gelandangan, mendirikan panti asuhan, dan

123 Erickson, Pandangan Kontemporer dalam Eskatologi, 67.

124 Erickson, Pandangan Kontemporer dalam Eskatologi, 65. 
lain-lain. ${ }^{125}$ William J. Seymour sendiri juga mengumandangkan pengajaran bahwa "Spirit Baptism was the power to draw all people into one church, irrespective of racial, ethnic, or social diversity." 126

Demikian juga gerakan Pentakosta, sejalan dengan postmilenialisme, mendukung perkembangan ilmu pengetahuan. Ini ditunjukkan dengan perhatian khusus yang ditekankan kaum Pentakosta pada pendidikan sekuler pada era modern ini. Menurut penelitian Yong, saat ini banyak sekolah-sekolah dan universitas-universitas yang didirikan oleh kaum Pentakosta sebagai tanda bahwa gerakan ini mendukung perkembangan ilmu pengetahuan di dunia ini. Yong menjelaskan,

One can note parallel developments in pentecostal higher education. The early pentecostal movement spawned a number of Bible schools, mission institutes, and other training centers focused on ministry and mission. Over the course of the twentieth century, some of these institutions were transformed into Bible colleges and then liberal arts colleges and universities; in addition, new colleges and seminaries were founded. By the end of the twentieth century, the United States boasted a wide network of accredited pentecostal and charismatic universities (including graduate and professional programs), and globally we have seen the emergence of pentecostal centers of higher education in Africa, South America, and the Pacific Islands. ${ }^{127}$

Demikian juga, Pentakosta juga tidak seluruhnya mengadopsi pandangan pesimis dari premilenialisme dispensasional bahwa segalanya akan dihancurkan pada akhirnya. Veli Matti Kärkäinen, sebaliknya, menyatakan bahwa Pentakosta adalah gerakan yang optimis, "Although tension among Pentecostals still continues between those with a view which emphasizes the 'other-worldliness' of the hope and those with a view towards improvement of the present, for most Pentecostals eschatological hope has brought with it optimism about the work they are doing."128 Sikap optimis ini disebabkan karena kaum Pentakosta percaya bahwa umat percaya diberikan kuasa Roh Kudus untuk mengerjakan pemulihan dunia ini. Karkainen berkata, "Pentecostals believe that when Christians are empowered with the Spirit of God, they are equipped to do 'kingdom works' in the midst of human suffering and plight."129

125 Gary B. McGee, “Tongues, The Bible Evidence: The Revival Legacy of Charles F. Parham,” Enrichment Journal (Summer, 1999), http://enrichmentjournal.ag.org/199903/068 tongues.cfm, diakses tanggal 18 Desember 2018.

${ }^{126}$ Ian MacRobert, "The Black Roots of Pentecostalism," Pentecost, Mission, and Ecumenism: Essays on Intercultural Theology, ed. Jan A. B. Jongeneel (Frankfurt am Main: Verlaf Peter Lang Gmbh, 1992), 9.

127 Yong, Renewing Christian Theology, 4.

${ }^{128}$ Veli Matti Kärkäinen, "Pentecostal Missiology in Ecumenical Perspective: Contributions, Challenges, Controversies," International Review of Mission Vol. LXXXVIII No. 350 (1999): 211.

${ }^{129}$ Kärkäinen, “Pentecostal Missiology in Ecumenical Perspective," 212. 
Postmilenialisme Bersyarat: Postmilenialisme dalam Spiritualitas Pentakosta

Dari analisa di atas, dapat dikatakan bahwa postmilenialisme merupakan sebuah cara pandang eskatologi yang cukup sesuai dengan teologi Pentakosta. Namun demikian, bukan berarti postmilenialisme dapat diterima mentah-mentah sebagai eskatologi Pentakosta. Menurut penulis, sebagaimana yang telah dijelaskan dan dievaluasi di atas, pandangan postmilenialisme tidak bertentangan dengan gerakan Pentakosta secara doktrinal. Namun ada beberapa hal yang perlu disesuaikan dalam pandangan postmillenialisme agar lebih sesuai dengan semangat dan spiritualitas Pentakosta. ${ }^{130}$

Pertama, banyak pengikut postmilenialisme cenderung tidak terlalu mempedulikan adanya hal-hal supranatural seperti mujizat, karunia roh, dan lain-lain dalam misi penginjilan di dunia ini. Hal ini disebabkan karena kaum postmilenial meyakini bahwa Allah selalu bekerja melalui gereja dan lewat hal-hal yang natural, contohnya dalam hal sosial atau politik. Namun bukan berarti kaum postmilenialis dapat digolongkan sebagai cessasionist sebagaimana kaum dispensasionalis fundamental. Postmilenialisme tidak pernah menggolongkan diri sebagai cessasionist. Namun fakta ini menunjukkan bahwa postmilenialisme pun harus disesuaikan dengan semangat Pentakosta yang meyakini hal-hal supranatural. Steven J. Land menegaskan bahwa karunia roh harus merupakan ciri misi Pentakosta, "In prayer for and ministry to the sick, oppressed, demonized and suffering, Pentecostals could participate with other Christians in a missionary praxis which would be at once a sign of the last-days' ministry, a gift of the Holy Spirit, a sacrament symbolizing the mystery of redemption..."131 Postmilenialisme bersyarat (conditional postmillennialism) masih memegang doktrin postmilenialisme tentang akhir zaman, namun bersamaan dengan itu juga harus mempercayai hal-hal supranatural seperti mujizat, karunia roh, dan lain-lain. Hal itu harus merupakan syarat utama jika kita ingin mengadopsi pandangan postmilenialisme sebagai eskatologi Pentakosta.

Demikian juga, postmilenialisme Pentakosta harus bercirikan kesalehan, sebagaimana yang dicirikan oleh spiritualitas Pentakosta. Kesalehan ini diaktualisasikan

130 Penyesuaian yang dimaksudkan penulis di sini bukan secara esensial yang merekonstruksi ulang keseluruhan pandangan postmilenialisme secara teologis, namun lebih kepada peran spiritualitas Pentakosta melengkapi pandangan postmilenialisme sehingga postmilenialisme dapat lebih sesuai dengan semangat gerakan Pentakosta. 45.

${ }^{131}$ Steven J. Land, “A Passion for the Kingdom: Revisioning Pentecostal Spirituality,” JPT 1 (1992): 
dalam doa dan ritual Pentakosta. Pandangan postmilenialisme yang bercirikan optimisme sangat mungkin untuk mengabaikan hal-hal seperti ini. Dalam bermisi, contohnya, kaum postmilenialis meyakini bahwa pasti banyak orang bertobat karena pemberitaan Injil. Pemberitaan Injil pasti sukses, karena sudah dijanjikan oleh Tuhan. Tetapi permasalahannya, bagaimana pertobatan itu dihasilkan? Apakah dari kehebatan pemberitaan manusia atau karena anugerah Tuhan? Thomas D. Ice mengkritik optimisme postmilenialisme yang seringkali terkesan arogan, “One wonders if they believe God's grace will give them success or if they think success will come from their own development, defense, and proclamation of their views." 132 Hal ini dapat dijawab dengan spiritualisme Pentakosta yang menekankan doa dalam segala sesuatu, termasuk dalam misi memberitakan Injil. Land menulis,

There is a distinctive Pentecostal spirituality which should be reflected in the process and results of the theological task. Prayer is necessary and not a mere 'pious addition' if that task is taken to be a discerning reflection upon lived reality by the eschatological, missionary community. Prayer expresses and evokes the apocalyptic affections which integrate and motivate the beliefs and practices of the community. ${ }^{133}$

Gerakan Pentakosta juga menekankan ritual sebagai bentuk dari spiritualitasnya. ${ }^{134}$ Ritual, menurut Daniel E. Albrecht, merupakan salah satu sarana di mana umat dapat mengevaluasi diri sendiri, di mana hal ini mencegah agar manusia tidak menjadi arogan, melainkan terus menerus bersedia ditransformasi. Ia menulis,

Rites experienced within the mode of contemplation are marked by an attitude of deep receptivity and docility toward God. In accord with this sensibility the potential for an arousal of self-conscious questioning, is actualized. In fact, pentecostal ritual participants repeatedly report being moved to the edge of profound self-investigation and exploration which in turn, frequently moves them toward moments of conversion and spiritual changes. ${ }^{135}$

132 Thomas D. Ice, “An Evaluation of Theonomic Neopostmillenialism," Bibliotheca Sacra (JulySeptember 1988): 292.

133 Land, "A Passion for the Kingdom," 45.

134 Ritual di sini merujuk kepada keseluruhan tata ibadah Pentakosta. Daniel E. Albrecht menjelaskan, "Ritual here is used to speak of the entire pentecostal service. We will use the term rite when referring to a portion or phase of the service (e.g., the sermon, the song service), a particular practice or specific enactment (e.g., laying on of hands and prayer, taking an offering, receiving water or Spirit baptism) or a set of actions (e.g., various types of altar/responses) recognized by Pentecostals as a legitimate part of their overall ritual." Lih. Daniel E. Albrecht, "Pentecostal Spirituality: Looking Through the Lens of Ritual," Pneuma Vol. 14, No. 2 (Fall, 1992): 108.

135 Albrecht, "Pentecostal Spirituality: Looking Through the Lens of Ritual," 124. 
Menurut penulis, spiritualitas Pentakosta ini melengkapi pandangan postmilenialisme yang rentan untuk berfokus kepada kekuatan manusia dan optimisme pada diri sendiri, menjadi pandangan yang tetap rendah hati dan bergantung pada Tuhan dalam melaksanakan amanat agung Tuhan maupun dalam hidup sehari-hari. Sebaliknya, pandangan postmilenialisme yang tidak sekedar menekankan ritual dan kesalehan melainkan juga tindakan nyata lewat aksi-aksi sosial dan kemanusiaan merupakan pelengkap yang sepadan untuk spiritualitas Pentakosta.

Hal kedua yang perlu dicermati adalah kecenderungan kaum postmilenialis untuk memiliki sikap optimisme yang berlebihan. Tidak diragukan bahwa optimisme adalah bagian dari postmilenialisme. Namun optimisme yang berlebihan tidak jarang menjadi ekses dalam pandangan ini. Optimisme berlebihan khususnya banyak dianut oleh orangorang yang menganut pandangan postmilenialisme baru/neo-postmillenialisme. Pandangan neo-postmilenialisme dibedakan dengan postmilenialisme klasik/Injili, di mana pandangan neo-postmilenialisme bercirikan optimisme berlebihan bahwa dunia akan diperintah seutuhnya oleh Kristus, dicirikan melalui pemerintahan gereja secara politis, dan lebih berfokus pada Injil sosial yang berfokuskan pada revolusi dan aksi-aksi sosial daripada metode penginjilan konservatif. ${ }^{136}$ Pandangan neo-postmilenialisme ini telah dianut oleh banyak kaum Karismatik, di mana ciri optimistik neo-postmilenialisme dianggap cocok dengan spiritualitas Karismatik yang juga optimis. ${ }^{137}$ Bukan tidak mungkin bahwa neo-postmilenialisme akan lebih mudah masuk ke dalam gerakan Pentakosta karena telah terlebih dahulu masuk ke dalam lingkungan Karismatik.

Neo-postmilenialisme memiliki optimisme berlebihan karena mereka meyakini kemampuan gereja untuk kembali mendatangkan kedamaian dan kemenangan di bumi bahkan sebelum Kristus belum datang kedua kali. Justru mereka berpendapat bahwa semakin agresif mereka menegakkan pemerintahan Kristus dunia, maka Kristus akan semakin cepat datang kedua kali. Agresivitas ini tidak hanya berlaku dalam pemberitaan Injil, namun juga dalam hal sosial dan politik. Neo-postmilenialisme mempercayai bahwa Kekristenan juga akan memimpin dalam hal sosial dan politik. Oleh sebab itu neopostmilenial lebih berfokus pada aksi-aksi sosial dan politik daripada kaum postmilenialis klasik/Injili.

136 Lih. Ice, "An Evaluation of Theonomic Neopostmillenialism," 290.

137 Lih. Ice, "An Evaluation of Theonomic Neopostmillenialism," 288, dan David Q. Santos, "Postmillenial Thought and the Kingdom," Journal of Dispensational Theology (Dec 2011): 33. 
Bagaimana gerakan Pentakosta menanggapi neo-postmilenialisme ini? Penulis berpendapat bahwa neo-postmilenalisme, sebagai aliran baru dari postmilenialisme harus disambut oleh kaum Pentakosta, namun juga perlu mengalami penyesuaianpenyesuaian. Neo-postmilenialisme layak disambut dalam kesediaan mereka ikut serta dalam aksi-aksi sosial politik, serta optimisme bahwa orang-orang Kristen harus memimpin dalam aspek sosial politik. Hal ini juga sejalan dengan spiritualitas Pentakosta yang didefinisikan Tae Young So sebagai "spirituality that aims at overcoming the dichotomy between God and the world."138 Non-dikotomi ini adalah hal yang tidak mungkin diterima oleh penganut premilenialisme dispensasional yang pesimis terhadap dunia. Keikutsertaan orang Kristen dalam ranah politik, sebaliknya, merupakan visi yang ideal dan Alkitabiah di mana Allah berjanji akan mewujudkan pemerintahan-Nya lewat gereja di dunia ini.

Di satu sisi, pandangan neo-postmilenialisme juga harus mengalami penyesuaian, sehubungan dengan optimisme dan agresivitas yang berlebihan. Optimisme dan agresivitas yang berlebihan sangat berbahaya karena bisa mendorong paham radikalisme. Radikalisme sangat tidak Alkitabiah, karena bukan bercirikan kasih, melainkan pemaksaan kehendak dan haus akan kekuasaan. David Q. Santos mengkritik pandangan neo-postmilenialisme sebagai bentuk Kristen dari Marxisme/ komunisme/sosialisme dan sebaliknya, Marxisme sebagai bentuk ateistik dari NeoPostmilenialisme. ${ }^{139}$ Sejalan dengan itu, Gary North berpendapat bahwa paham optimisme berlebihan akan membawa pada radikalisme yang bercirikan kekerasan. Ia menulis,

If all a person gains from the Christian Reconstruction movement in general is its optimistic eschatology, then he is skating on thin ice. Optimism is not enough. In fact, optimism alone is highly dangerous. The Communists have a doctrine of inevitable victory, so do radical Muslims. So did a group of revolutionary communist murderers and polygamists, the Anabaptists who captured the German city of Munster from 1525-35, before they were defeated militarily by Christian forces. Optimism in the wrong hands is a dangerous weapon. ${ }^{140}$

Radikalisme yang tidak pernah bercirikan kasih, melainkan selalu bercirikan pemaksaan kehendak, bahkan kadang kekerasan ini juga sangat bertentangan dengan

138 Tae Young So, "Pentecostal Spirituality as Nurturing Vitality for Human Lives," Journal of Pentecostal Theology 18 (2009): 250.

139 Santos, "Postmillenial Thought and the Kingdom," 23.

140 Gary North, "Chilton, Sutton, and Dominion Theology," e-article, https://www.garynorth.com/ freebooks/docs/a_pdfs/newslet/position/8701.pdf, diakses 25 Desember 2018. 
spiritualisme Pentakosta, yang walaupun optimis, tetapi tidak pernah mengabaikan kasih. Land menjelaskan,

Spirit baptism and ongoing filling intensifies and focuses that hope which saves even as it reaches to lift, save and encourage others... The Pentecostal outpouring in the first and twentieth centuries resulted in the increase of faith, hope and love for millions of disinherited but not abandoned men, women and children. ${ }^{141}$

Oleh sebab itu, penulis berpendapat bahwa neo-postmilenialisme yang dapat diadopsi gerakan Pentakosta lebih baik mengambil posisi "realisme yang berpengharapan“ kepada Allah. ${ }^{142}$ Eka Darmaputera menjelaskan realisme yang berpengharapan sebagai berikut, "Realisme, oleh karena kita menyadari betapa ringkihnya kita dan betapa rawannya keadaan. Tetapi berpengharapan, karena selalu terbuka kemungkinan."143 Jika diaplikasikan, realisme yang berpengharapan ini optimis bahwa gereja dipakai Tuhan untuk memerintah di bumi ini, bahkan secara sosial dan politik, namun di sisi lain gereja juga tidak menjadi agresif dan memaksakan kehendaknya, sebagaimana yang dilakukan kaum radikal. Gereja boleh berharap akan hal itu, tetapi mereka tetap menggantungkan diri pada kehendak Allah. Motivasi gereja untuk memerintah juga tidak boleh didasari oleh keinginan untuk berkuasa, melainkan kasih, yaitu supaya pemerintahan Allah yang adil melingkupi seluruh dunia. Dengan demikian, gereja juga tidak boleh melakukan kekerasan, penjajahan, dan penindasan hanya karena ingin menjadi penguasa dalam hal sosial politik atau pemerintahan. Justru jika gereja masih mengalami kegagalan-kegagalan dalam memerintah dunia ini, itu menyebabkan gereja semakin bergairah menantikan kedatangan Kristus kedua kali. Dalam hal ini penulis setuju dengan ungkapan Santos, "Those that know Jesus Christ patiently wait for His imminent return... Mankind longs to have the creation restored and the world to be ruled by the true king, Jesus Christ."144 Menurut penulis, hanya spiritualitas Pentakosta yang rendah hati dan bergantung pada Allah, yang dapat menahan neo-postmilenialisme jatuh ke dalam optimisme yang berlebihan ini.

Dari dua aspek yang telah dibahas di atas, dapat disimpulkan bahwa postmilenialisme, bahkan neo-postmilenialisme, dapat dijadikan sebagai kerangka

141 Land, "A Passion for the Kingdom," 45.

142 Istilah realisme yang berpengharapan diambil Eka Darmaputera dari Dr. T.B. Simatupang, lih. Eka Darmaputera, "Menantikan Seorang Musa," dalam Pergulatan Kehadiran Kristen di Indonesia, eds. Martin L. Sinaga, et. al (Jakarta: BPK Gunung Mulia, 2005), 326.

143 Eka Darmaputera, "Rekonstruksi Etika Kristen," dalam Pergulatan Kehadiran Kristen di Indonesia, eds. Martin L. Sinaga, et. al (Jakarta: BPK Gunung Mulia, 2005), 689.

144 Santos, "Postmillenial Thought and the Kingdom," 34. 
eskatologi Pentakosta, asalkan mengalami beberapa penyesuaian. Dalam postmilenialisme bersyarat, dapat dilihat bagaimana teologi Pentakosta dan pandangan postmilenialisme saling mengisi untuk menjadi sebuah model eskatologi yang harmonis dan seimbang.

\section{Kesimpulan}

Artikel ini membantah konsep premilenialisme dispensasional sebagai konsep eskatologi yang khas Pentakosta. Ada beberapa konsep premilenialisme dispensasional yang tidak cocok dengan teologi Pentakosta klasik, antara lain: 1. Pemisahan Israel dengan Gereja, 2. Konsep tribulasi dan pengangkatan gereja, 3. Keyakinan dispensasionalis bahwa karunia-karunia roh berhenti di zaman rasul-rasul (cessasionist), 4. Sikap pesimis terhadap dunia saat ini.

Sebaliknya penulis melihat bahwa konsep postmilenialisme lebih cocok dengan semangat dan teologi Pentakosta. Alasannya adalah bahwa konsep postmilenialisme bukan konsep yang jauh sama sekali dalam sejarah gerakan Pentakosta, mengingat bahwa tidak semua cabang Pentakosta mengikuti tren premilenialisme di zaman itu, contohnya aliran kekudusan Wesleyan yang masih menganut postmilenialisme.

Namun demikian untuk menghasilkan konsep eskatologi yang khas Pentakosta, postmilenialisme juga harus mengalami beberapa penyesuaian (postmilenialisme bersyarat), antara lain: 1 . Postmilenialisme Pentakosta harus terbuka terhadap hal-hal yang supranatural sesuai dengan kepercayaan Pentakosta terhadap karunia Roh dan mujizat, 2. Postmilenialisme Pentakosta tidak boleh kehilangan spiritualitas kesalehan yang menjadi ciri khas gerakan kekudusan dalam Pentakostalisme, 3. Postmilenialisme dapat bergabung dalam aksi sosial dan politik, namun tidak boleh jatuh ke dalam optimisme yang berlebihan, 4. Optimisme dalam pandangan postmilenialisme tidak boleh melenyapkan semangat dan gairah Pentakosta dalam menantikan kedatangan Kristus yang kedua kali, sesuai dengan semangat mula-mula yang ditanam oleh BapakBapak Pentakosta awal.

\section{DAFTAR PUSTAKA}

Albrecht, Daniel E. "Pentecostal Spirituality: Looking Through the Lens of Ritual.“ Pneuma Vol. 14, No. 2 (Fall, 1992): 107-125. 
Althouse, Peter. "Pentecostal Eschatology in Context: The Eschatological Orientation of the Full Gospel." Dalam Perspective in Pentecostal Eschatology: World Without End, diedit oleh Peter Althouse dan Robby Wadell. Cambridge: James Clarke \& Co, 2012, 205-231.

Althouse, Peter. Spirit of the Last Days: Pentecostal Eschatology in Conversation with Jurgen Moltmann. London: T\&T Clark, 2003.

Balfour, Glenn. “Pentecostal Eschatology Revisited.” JEPTA Vol. 2 (2011): 127-140.

Bertone, John A. "Seven Dispensations or Two-Age View of History.” Dalam Perspective in Pentecostal Eschatology: World Without End, diedit oleh Peter Althouse dan Robby Wadell. Cambridge: James Clarke \& Co, 2012, 61-94.

Darmaputera, Eka. "Menantikan Seorang Musa." Dalam Pergulatan Kehadiran Kristen di Indonesia, diedit oleh Martin L. Sinaga, Trisno S. Susanto, Sylvana Ranti-Apituley, dan Adi Pidekso (Jakarta: BPK Gunung Mulia, 2005), 325-331.

Darmaputera, Eka. "Rekonstruksi Etika Kristen." Dalam Pergulatan Kehadiran Kristen di Indonesia diedit oleh Martin L. Sinaga, Trisno S. Susanto, Sylvana Ranti-Apituley, dan Adi Pidekso (Jakarta: BPK Gunung Mulia, 2005), 679-695.

Darby, J.N. "The Rapture of the Saints," Collected Writings, Vol. 2.

Dempster, Murray W. "Christian Social Concern in Pentecostal Perspective:

Reformulating Pentecostal Eschatology." Journal of Pentecostal Theology 2 (1993): 51-64.

Erickson, Millard J. Pandangan Kontemporer dalam Eskatologi: Sebuah Studi tentang Milenium. Malang: Literatur SAAT, 2009.

Hoekema, Anthony. Alkitab dan Akhir Zaman. Surabaya: Momentum, 2000.

Ice, Thomas D. "An Evaluation of Theonomic Neopostmillenialism," Bibliotheca Sacra (July-September 1988): 281-300.

Kärkäinen, Veli Matti. "Pentecostal Missiology in Ecumenical Perspective: Contributions, Challenges, Controversies." International Review of Mission Vol. LXXXVIII No. 350 (1999): 207-225.

Kärkäinen, Veli Matti. "Truth on Fire: Pentecostal Theology of Mission and the Challenges of a New Millenium." AJPS 3/1 (2000): 33-60.

Lamp, Jeffrey S. "New Heavens and New Earth: Early Pentecostal Soteriology as a Foundation for Creation Care in the Present." Pneuma 36 (2014): 64-80.

Land, Steven J. "A Passion for the Kingdom: Revisioning Pentecostal Spirituality." JPT 1 (1992): 19-46. 
Langer, Rick. "Kingdom Integration: Reflections on Premillennialism and Cultural Engagement.” CTR 10/1 (Fall 2012): 21-39.

Ma, Wonsuk. "Pentecostal Eschatology: What Happenned When the Wave Hit the West End of the Ocean." AJPS 12:1 (2009): 95-112.

MacRobert, Ian. "The Black Roots of Pentecostalism." Dalam Pentecost, Mission, and Ecumenism: Essays on Intercultural Theology, diedit oleh Jan A. B. Jongeneel. Frankfurt am Main: Verlaf Peter Lang Gmbh, 1992.

McGee, Gary B. "Tongues, The Bible Evidence: The Revival Legacy of Charles F. Parham.” Enrichment Journal (Summer, 1999), http://enrichmentjournal.ag.org/199903/068 tongues.cfm, diakses tanggal 18 Desember 2018.

McQueen, Larry. "Early Pentecostal Eschatology in the Light of the Apostolic Faith." Dalam Perspective in Pentecostal Eschatology: World Without End, diedit oleh Peter Althouse dan Robby Wadell. Cambridge: James Clarke \& Co, 2012, 139-154.

Menzies, William W. "Non-Wesleyan Pentecostalism: A Tradition, The Influence of Fundamentalism." AJPS 14:2 (2011): 199-211.

North, Gary. "Chilton, Sutton, and Dominion Theology." E-article, https://www.garynorth.com/freebooks/docs/a_pdfs/newslet/position/ 8701.pdf, diakses 25 Desember 2018.

Santos, David Q. "Postmillenial Thought and the Kingdom." Journal of Dispensational Theology (Dec 2011): 21-34.

Sheppard, Gerald T. "Pentecostal and the Hermeneutics of Dispensationalism: The Anatomy of an Uneasy Relationship." Pneuma, Journal of Society for Pentecostal Studies (Fall, 1984): 5-33.

So, Tae Young. "Pentecostal Spirituality as Nurturing Vitality for Human Lives." Journal of Pentecostal Theology 18 (2009): 246-262.

Vondey, Wolfgang. Pentecostal Theology: Living the Full Gospel. London: Bloomsbury T\&T Clark, 2017.

Yong, Amos. Renewing Christian Theology: Systematic for a Global Christianity. Texas: Baylor University Press, 2014, e-book.

Tentang penulis:

Jessica Novia Layantara, M.Th. Memperoleh gelar S.Th. dari STT Satyabhakti (SATI), Malang (2010). Memperoleh gelar M.Th. dari STT Amanat Agung, Jakarta (2015). Saat ini mengajar sebagai dosen penuh waktu di Universitas Pelita Harapan, Karawaci. Email: jessica_layantara88@yahoo.com /Phone: +62899-089-1119. 